\title{
Dazed and Diffused: A Hands-On Approach to Understanding Diffusion in Biology
}

\author{
Adam Stabell, Nicholas Roussel, Eric Tarapore, and Debra Mauzy-Melitz
}

\author{
University of California Irvine, Department of Developmental \& Cell Biology, 4340 McGaugh \\ Hall, Ring Rd, Irvine CA 92697 USA \\ (astabell@uci.edu; dmauzyme@uci.edu)
}

\begin{abstract}
Whether through gas exchange in the lungs during respiration, neurotransmission across the synapses, or water molecules moving across the cells lining your intestines - diffusion and osmosis play a critical role in everyday life. Primarily taught in physics and chemistry classes, this key concept is often overlooked in biology labs. While diffusion is important for understanding chemical and physical processes, it is equally important for understanding many biological processes. Fostered by an activity that emphasizes and demonstrates key concepts of diffusion and osmosis, this active learning exercise allows students to creatively use common laboratory and household items to devise a simple and practical example of diffusion. To reinforce this activity, we concluded with a discussion of other examples of diffusion and osmosis created using these items allowing students to visualize the many ways that these simple items can demonstrate such an important concept. Participants were given a variety of miscellaneous items that they used to demonstrate diffusion in this guided activity.
\end{abstract}

Keywords: diffusion, osmosis, active learning, guided activity

\section{Mission, Review Process \& Disclaimer}

The Association for Biology Laboratory Education (ABLE) was founded in 1979 to promote information exchange among university and college educators actively concerned with teaching biology in a laboratory setting. The focus of ABLE is to improve the undergraduate biology laboratory experience by promoting the development and dissemination of interesting, innovative, and reliable laboratory exercises. For more information about ABLE, please visit http:// www.ableweb.org/.

Advances in Biology Laboratory Education is the peer-reviewed publication of the conference of the Association for Biology Laboratory Education. Published articles and extended abstracts are evaluated and selected by a committee prior to presentation at the conference, peer-reviewed by participants at the conference, and edited by members of the ABLE Editorial Board. Published abstracts are evaluated and selected by a committee prior to presentation at the conference.

\section{Citing This Article}

Stabell A, Roussel N, Tarapore E, Mauzy-Melitz D. 2020. Dazed and diffused: A hands-on approach to understanding diffusion in biology. Article $53 \mathrm{In}$ : McMahon K, editor. Advances in biology laboratory education. Volume 41. Publication of the 41st Conference of the Association for Biology Laboratory Education (ABLE). https://doi.org/10.37590/ able.v41.abs53

Compilation (C) 2020 by the Association for Biology Laboratory Education, ISBN 1-890444-17-0. All rights reserved. No part of this publication may be reproduced, stored in a retrieval system, or transmitted, in any form or by any means, electronic, mechanical, photocopying, recording, or otherwise, without the prior written permission of the copyright owner.

ABLE strongly encourages individuals to use the exercises in this volume in their teaching program. If this exercise is used solely at one's own institution with no intent for profit, it is excluded from the preceding copyright restriction, unless otherwise noted on the copyright notice of the individual chapter in this volume. Proper credit to this publication must be included in your laboratory outline for each use; a sample citation is given above. 